\title{
ANALISIS PENERAPAN E-FAKTUR DAN E-NOFA PADA PT. RAJAWALI PROPERTY JAYA
}

\author{
Laode Muhammad Hasrul Adan \\ Program Studi Akuntansi, Fakultas Ekonomi \\ Universitas Muhammadiyah Buton, Baubau, Indonesia \\ e-mail: laodehasrul.umb@gmail.com
}

\begin{abstract}
ABSTRAK
Tujuan penelitian ini untuk mengetahui penerapan $e$-Faktur dan $e$-Nofa dan kendala apa yang dihadapi Pengusaha Kena Pajak. Oleh karena itu penelitian ini diharapkan berguna sebagai bahan informasi bagi kalangan akademisi dan sebagai bahan masukan bagi para pengambil keputusan. Penelitian ini menggunakan metode analisis data statistik deskriptif. Sumber data diperoleh dari dokumentasi, wawancara dan observasi pada PT. Rajawali Property Jaya.

Hasil dari penelitian ini yaitu penerapan e-Faktur dalam pembuatan faktur pajak pada perusahaan sudah berjalan dengan baik, peneliti menemukan penerapan e-nofa memiliki keunggulan serta kelemahan. Keunggulannya antara lain yaitu lebih tertib adminitrasi dibandingkan dengan sebelum penerapan serta dapat meminimalisir terjadinya kecurangan seperti penerbitan faktur pajak fiktif dan faktur pajak nomor berganda. Sedangkan kelemahan dari penerapan e-nofa adalah yaitu koneksi internet dan ketergantungan dengan jaringan internet sedangkan penyebaran internet masih belum merata secara nasional, sehingga dalam membuat faktur pajak harus memiliki koneksi internet terlebih dahulu, sehingga ruang gerak perusahaan agak terbatas untuk membuat dan mencetak faktur pajak
\end{abstract}

Kata Kunci: e-Faktur, e-Nofa, Pengusaha Kena Pajak.

\begin{abstract}
The purpose of this research is to know implementation of the e-Faktur and e-Nofa as a repair system for the administration of value added tax. Therefore this study is expected to be useful as material information for academicians and as input for decision-makers. This research uses descriptive statistics data analysis methods. Source data obtained from the documentation, interviews and observations on PT. Rajawali Property Jaya.

The results of this study, namely the application of e-Invoice in making tax invoices on the company has been going well, researchers found the application of e-Nofa has advantages and disadvantages. Its advantages include more orderly administration compared to before implementation and can minimize the occurrence of fraud such as issuing fictitious tax invoices and multiple number tax invoices. While the weakness of the application of e-Nofa is the internet connection and dependence on the internet network while the spread of the internet is still not evenly distributed nationally, so in making tax invoices must have an internet connection first, so that the company's space is limited.
\end{abstract}

\section{Keywords: E-Faktur, E-Nofa, Taxable Entrepreneur for VAT Purposes..}




\section{PENDAHULUAN}

Reformasi perpajakan di Indonesia mengalami perubahan besar khususnya pada perubahan sistem administrasi pajak pertambahan nilai. Perubahantersebut dilatarbelakangi dengan tidakoptimalnya penerimaanpajak pertambahan nilai yang disebabkanoleh penyalahgunaan faktur pajak, yang mana banyaknya faktur pajak fiktif yang dibuat oleh perusahaan untuk menjadikan sebagai pengurang Pajak Pertambahan Nilainya, sehingga merugikan Negara.

Perkembangan teknologi digital memungkinkan Direktorat Jenderal Pajak untuk mengontrol faktur-faktur yang diterbitkan oleh Wajib Pajak khususnya Pengusaha Kena Pajak (PKP). Pemerintah melakukan reformasi disektor Pajak Pertambahan Nilai melalui aplikasi e-Faktur sebagai cara untuk meminimalisir terjadinya kecurangan dalam pelaporan pajak yang dapat merugikan negara. Penomoran faktur pajak yang semula dibuat oleh Pengusaha Kena Pajak itu sendiri kini diganti dengan menggunakan e-Nofa (Elektronik Nomor Faktur) Pajak. [1].

Pajak adalah iuran rakyat kepada kas Negara berdasarkan undang-undang (yang dapat dipaksakan) dengan tidak mendapat jasa timbal balik (kontraprestasi) yang langsung dapat ditunjukkan, dan yang digunakan untuk membayar pengeluaran umum. [2]. Pajak adalah prestasi kepada pemerintah yang terutang melalui norma-norma umum dan yang dapat dipaksakan, tanpa adanya kontraprestasi yang dapat ditunjukkan dalam hal yang individual, dimaksud untuk membiayai pengeluaran pemerintah. [3]

Berdasarkan beberapa definisi di atas dapat disimpulkan karakteristik pajak sebagai berikut :

a. Arus uang (bukan barang) dari rakyat ke kas Negara.

b. Pajak dipungut berdasarkan undang-undang (yang dapat dipaksakan).

c. Tidak ada timbal balik khusus atau kontraprestasi secara langsung yang dapat ditunjukkan.

d. Pajak digunakan untuk membiayai pengeluaran-pengeluaran secara umum demi kemakmuran rakyat.

Penomoran seri faktur pajak bertujuan untuk mempermudah pengadministrasian setiap transaksi yang dilakukan oleh pengusaha kena pajak. Pada awalnya penomoran seri faktur pajak dilakukan sendiri oleh wajib pajak. Wajib pajak memiliki wewenang untuk memberi nomor seri faktur pajak dan melaporkannya, namun, beberapa tahun terakhir terjadi penyelewengan pajak yang disebabkan oleh faktur pajak fiktif. [4]. 
Menurut Halim Faktur pajak adalah bukti pungutan pajak yang dibuat oleh pengusaha kena pajak yang melakukan penyerahan barang kena pajak atau penyerahan jasa kena pajak. [3]

Pengusaha kena pajakberkewajiban, antara lain untuk [5]:

a. Melaporkan usahanya untuk dikukuhkan menjadi pengusaha kena pajak.

b. Memungut pajak pertambahan nilai dan pajak pertambahan nilai atas barang mewah.

c. Menyetorkan pajak pertambahan nilai yang masih harus dibayar dalam hal pajak keluaran lebih besar daripada pajak masukan yang dapat dikreditkan serta menyetorkan pajak penjualan atas barang mewah yang terutang, dan

d. Melaporkan perhitungan pajak.

Pengusaha kena pajak mempunyai hak, diantaranya [5]:

a. Menerbitkan faktur pajak hanya boleh diterbitkan oleh pengusaha yang telah dikukuhkan sebagai pengusaha kena pajak karena faktur pajak yang dimiliki oleh pembeli merupakan pajak masukan yang dapat dikreditkan oleh pembeli, sehingga pengusaha yang belum dikukuhkan sebagai pengusaha kena pajak tidak mempunyai hak untuk membuat faktur pajak.

b. Mengkreditkan pajak masukan, pengusaha yang telah dikukuhkan sebagai pengusaha kena pajak tidak mempunyai hak untuk mengkreditkan pajak masukan yang didapatkan dari penjual.

c. Meminta kembali kelebihan pajak, pengusaha yang telah dikukuhkan sebagai pengusaha kena pajak dapat meminta kembali apabila terdapat kelebihan pajak pertambahan nilai atau pajak pertambahan nilai atas barang mewah yang telah dibayar atau telah dipungut pihak lain.

Aplikasi e-Faktur merupakan aplikasi yang disediakan oleh Direktorat Jenderal Pajak sebagai perbaikan sistem administrasi perpajakan yang ada. Dalam penggunaannya aplikasi ini harus terkoneksi dengan jaringan internet. Kantor pelayanan pajak senantiasa mengadakan sosialisasi e-Faktur, setiap sosialisasi yang diadakan, bertujuan untuk memberitahukan tata cara pendaftaran e-Faktur, tujuan dan dasar hukum e-Faktur, serta sistem kerja e-Faktur. [7] . Dalam sosialisasi tersebut, setiap wakil dari wajib pajak akan diberikan compact disc (CD) yang berisi aplikasi e-Faktur dummy, materi sosialisasi eFaktur, video tutorial e-Faktur, serta kumpulan pertanyaan mengenai e-Faktur. Setiap 
peserta sosialisasi diwajibkan untuk membawa laptop untuk mempraktikkan langsung aplikasi e-Faktur pada waktu sosialisasi.

Pada waktu sosialisasi dilakukan, seluruh peserta wajib menggunakan aplikasi eFaktur dummy dengan mengikuti instruktur sosialisasi. Untuk selanjutnya, aplikasi eFaktur dummy tersebut dapat digunakan masing-masing peserta sebagai latihan setelah sosialisasi selesai dilaksanakan. Aplikasi tersebut dapat memudahkan setiap orang yang ingin belajar e-Faktur, tanpa harus takut jika data yang digunakan ter-upload di aplikasi Direktorat Jenderal Pajak. Mengingat aplikasi e-Faktur tersebut tidak terkoneksi dengan internet dan tidak terhubung langsung dengan aplikasi Direktorat Jenderal Pajak.

Pajak Pertambahan Nilai dikenakan atas pertambahan nilai yang terjadi karena kegiatan-kegiatan sebagai berikut [8]:

a. Penyerahan Barang Kena Pajak di dalam Daerah Pabean yang dilakukan oleh pengusaha. Pengusaha yang melakukan kegiatan penyerahan Barang Kena Pajak meliputi baik pengusaha yang telah dikukuhkan menjadi Pengusaha Kena Pajak sebagaimana dimaksud dalam pasal 3A ayat (1) Undang-Undang Pajak Pertambahan Nilai (PPN) maupun pengusaha yang seharusnya dikukuhkan menjadi Pengusaha Kena Pajak, tetapi belum dikukuhkan. Penyerahan barang yang dikenai pajak harus memenuhi syarat-syarat sebagai berikut:

1) Barang berwujud yang diserahkan merupakan Barang Kena Pajak

2) Barang tidak berwujud yang diserahkan merupakan Barang Kena Pajak Tidak Berwujud

3) Penyerahan dilakukan di dalam Daerah Pabean

4) Penyerahan dilakukan dalam rangka kegiatan usaha atau pekerjaannya.

b. Impor Barang Kena Pajak. Pemungutan dilakukan melalui Direktorat Jenderal Bea dan Cukai. Siapapun yang memasukkan Barang Kena Pajak ke dalam Daerah Pabean, tanpa memperhatikan apakah dilakukan dalam rangka kegiatan usaha atau pekerjaannya atau tidak, tetap dikenai pajak.

c. Penyerahan Jasa Kena Pajak di dalam Daerah Pabean yang dilakukan oleh pengusaha. Pengusaha yang melakukan kegiatan penyerahan Jasa Kena Pajak meliputi baik pengusaha yang telah dikukuhkan sebagai Pengusaha Kena Pajak sebagaimana dimaksud dalam pasal 3A ayat (1) Undang-Undang PPN maupun pengusaha yang seharusnya dikukuhkan sebagai Pengusaha Kena Pajak, tetapi 
belum dikukuhkan. Penyerahan jasa yang terutang pajak harus memenuhi syaratsyarat sebagai berikut:

1) Jasa yang diserahkan merupakan Jasa Kena Pajak

2) Penyerahan dilakukan di dalam Daerah Pabean

3) Penyerahan dilakukan dalam kegiatan usaha atau pekerjaannya

d. Pemanfaatan Barang Kena Pajak Tidak Berwujud dari luar Daerah Pabean di dalam Daerah Pabean. Untuk dapat memberikan perlakuan pengenaan pajak yang sama dengan impor Barang Kena Pajak, atas Barang Kena Pajak Tidak Berwujud yang berasal dari luar Daerah Pabean yang dimanfaatkan oleh siapapun di dalam Daerah Pabean juga dikenai Pajak Pertambahan Nilai. Contoh:Pengusaha A yang berkedudukan di Jakarta memperoleh hak menggunakan merek yang dimiliki pengusaha B yang berkedudukan di Hong Kong. Atas pemanfaatan merek tersebut oleh Pengusaha A di dalam Daerah Pabean terutang Pajak Pertambahan Nilai.

e. Pemanfaatan Jasa Kena Pajak dari luar Daerah Pabean di dalam Daerah Pabean. Jasa yang berasal dari luar Daerah Pabean yang dimanfaatkan oleh siapapun di dalam Daerah Pabean dikenai Pajak Pertambahan Nilai. Contoh: Pengusaha Kena Pajak C di Surabaya memanfaatkan Jasa Kena Pajak dari Pengusaha B yang berkedudukan di Singapura. Atas pemanfaatan Jasa Kena Pajak tersebut terutang Pajak Pertambahan Nilai.

f. Ekspor Barang Kena Pajak Berwujud oleh Pengusaha Kena Pajak. Pengusaha yang melakukan ekspor Barang Kena Pajak Berwujud hanya pengusaha yang telah dikukuhkan menjadi Pengusaha Kena Pajak.

g. Ekspor Barang Kena Pajak Tidak Berwujud oleh Pengusaha Kena Pajak. Pengusaha yang melakukan ekspor Barang Kena Pajak Tidak Berwujud hanya pengusaha yang telah dikukuhkan menjadi Pengusaha Kena Pajak.

h. Ekspor Jasa Kena Pajak oleh Pengusaha Kena Pajak. Termasuk dalam pengertian ekspor Jasa Kena Pajak adalah penyerahan Jasa Kena Pajak dari dalam Daerah Pabean ke luar Daerah Pabean oleh Pengusaha Kena Pajak yang menghasilkan dan melakukan ekspor Barang Kena Pajak Berwujud atas dasar pesanan atau permintaan dengan bahan dan atas petunjuk dari pemesan di luar Daerah Pabean.

i. Kegiatan membangun sendiri yang dilakukan tidak dalam kegiatanusaha atau pekerjaan oleh orang pribadi atau badan yang hasilnya digunakan sendiri atau digunakan pihak lain. 
j. Penyerahan Barang Kena Pajak berupa aset yang menurut tujuan semula tidak untuk diperjualbelikan oleh Pengusaha Kena Pajak, kecuali atas penyerahan aset yang Pajak Masukannya tidak dapat dikreditkan.

Secara sederhana, aplikasi e-Faktur dapat dikatakan sebagai sebuah aplikasi elektronik yang digunakan untuk menerbitkan faktur pajak dan membuat laporan SPT Masa PPN 1111. Aplikasi ini menggantikan sekaligus memperbaiki aplikasi yang sudah ada sebelumnya, yaitu $e$-SPT PPN 1111. Saat menggunakan aplikasi E-spt, user harus menerbitkan faktur pajak secara tersendiri/manual dan barulah saat akan membuat laporan SPT Masa PPN aplikasi e-SPT PPN 1111 dijalankan. Dengan aplikasi e-Faktur, kedua hal tersebut kini telah disatukan. [9]

Ketentuan tentang penerbitan faktur pajak berbentuk elektronik melalui aplikasi e-Faktur, didasarkan pada aturan sebagai berikut, yaitu:

a. Peraturan Direktur Jenderal Pajak Nomor PER-16/PJ/2014 (berlaku 1 Juli 2014) tentang Tata Cara Pembuatan dan Pelaporan Faktur Pajak Berbentuk Elektronik; dan

b. Peraturan Direktur Jenderal Pajak Nomor PER-17/PJ/2014 (berlaku 1 Juli 2014) tentang perubahan atas PER-24/PJ/2012 (berlaku sejak 1 April 2013) tentang bentuk, ukuran, prosedur pemberitahuan dalam rangka pembuatan, tata cara pengisian keterangan, pembetulan atau penggantian, dan pembatalan faktur pajak. Dari kedua peraturan tersebut, faktur pajak elektronik pada prinsipnya tidak mengubah aturan umum tentang Pajak Pertambahan Nilai, seperti tentang saat dan tempat terutangnya Pajak Pertambahan Nilai, penggunaan jatah Nomor Seri Faktur Pajak, maupun tentang penggolongan Barang Kena Pajak/Jasa Kena Pajak sebagai objek Pajak Pertambahan Nilai. Hal yang berubah hanya berkisar tentang bagaimana cara teknis menerbitkan faktur pajak

Direktorat Jenderal Pajak terus melakukan upaya untuk mencegah penyelewengan tersebut. Salah satuupaya yang dilakukan adalah dengan menerbitkan eNofa. Perbedaan e-Nofa dengan penomoran seri faktur pajak sebelumnya yaitu terletak pada proses penomorannya. Penerbitan e-Nofa dilakukan secara terpusat oleh Direktorat Jenderal Pajak melalui kantor pelayanan pajak tempat wajib pajak terdaftar.

Proses permintaannya harus sesuai dengan peraturan yang berlaku, sehingga pengusaha kena pajak tidak memiliki wewenang lagi untuk menerbitkan nomor serifaktur pajak. Dalam PER-24/PJ/2012 disebutkan bahwa yang dimaksud dengan 
nomor seri faktur pajak adalah nomor seri yang diberikan oleh Direktorat Jenderal Pajak kepada pengusaha kena pajak dengan mekanisme tertentu untuk penomoran faktur pajak yang berupa kumpulan angka, huruf, atau kombinasi angka dan huruf yang ditentukan oleh Direktorat Jenderal Pajak.Berikut adalah format pemberian kode dan nomor seri faktur pajak:

\section{XXX.XX.XXXXXX}

\section{Keterangan :}

a. $\quad 12: 2$ (dua) digit kode transaksi

b. $\quad 3: 1$ (satu) digit kode status (ditandai dengan warna hitam) dan

c. XXX.XX.XXXXXX : 13 (tiga belas) digit nomor transaksi yang ditentukan oleh Direktur Jenderal Pajak

Pengisian kode transaksi dan kode status padanomor seri faktur pajak mengacu pada PER-24/PJ/2012. Pembuatan nomor seri faktur pajak pada umumnya tidaklah sulit Pengusaha Kena Pajak hanya perlu melihat substansinya kemudian mencocokannya dengan peraturan perpajakan yang berlaku. Untuk menjalankan aplikasi e-Faktur secara optimal, user perlu memahami tentang web e-Nofa.Web ini memuat informasi data profil Pengusaha Kena Pajak dan poin terpenting adalah tersedianya akses untuk mengajukan permintaan jatah Nomor Seri Faktur Pajak (NSFP) secara online. Cara menjalankan web e-Nofa adalah sebagai berikut:

a. Alamat URL web e-Nofa: https://efaktur.pajak.go.id/login;

b. Masukkan username berupa 15 digit NPWP tanpa penghubung;

c. Masukkan passworde-Nofa, yaitu password standar yang diberikan Kantor Pelayanan Pajak dan diterima Pengusaha Kena Pajak melalui email;

d. Pilih dan klik login, setelah login, pada bagian kiri terdapat menu dan layanan yang dapat digunakan.

e. Untuk mengakses menu permintaan Nomor Seri Faktur Pajak, dibutuhkan konfigurasi file sertifikat digital dan memperhatikan syarat telah melaporkan SPT Masa PPN untuk 3 (tiga) masa pajak terakhir yang telah jatuh tempo secara berturut-turut.

Penerapan sistem tersebut diatas tentu mendapatkan respon beragam dari Wajib Pajak, hal ini menjadi tantangan Direktorat Jenderal Pajak untuk memberikan pemaham 
kepada Wajib Pajak khususnya Pengusaha Kena Pajak (PKP). Berdasarkan latar belakang masalah yang telah diuraikan diatas maka permasalahan yang menjadi bahan pengkajian dalam penelitian ini adalah bagaimana penerapan e-Faktur dan e-Nofa di PT. Rajawali Property Jaya?. Penelitian ini bertujuan untuk mengetahui bagaimana penerapan e-Faktur dan e-Nofa dan kendala yang dihadapi PT. Rajawali Property Jaya.

\section{METODE PENELITIAN}

Jenis data yang digunakan yaitu data kualitatif dan data kuantitatif. Data kualitatif adalah data yang dinyatakan dalam bentuk angka dan kalimat. Sedangkan data kuantitatif adalah data yang berbentuk angka atau data kualitatif yang diangkakan [10]. Data penelitian berupa data tentang penerapan aplikasi e-Faktur dan e-Nofa dengan cara menghimpun fakta-fakta yang ada pada lokasi penelitian.

Sumber data yang digunakan dalam penelitian ini adalah data primer dan data sekunder. Data Primer, adalah data yang diperoleh secara langsung dari sumber asli (tidak melalui media perantara). Dapat berupa opini dari karyawan dan sistem aplikasi eFaktur dan e-Nofa.Data Sekunder merupakan data pendukung dan pelengkap yang tidak diusahakan sendiri pengumpulannya oleh penulis. Data sekunder penelitian ini berupa dokumentasi, arsip dan hal lain yang berhubungan dengan tema penelitian.

Pengertian populasi adalah wilayah generalisasi yang terdiri atas obyek/subyek yang mempunyai kualitas dan karakteristik tertentu yang ditetapkan oleh peneliti untuk dipelajari dan kemudian ditarik kesimpulannya. Sampel adalah bagian dari jumlah dan karakteristik yang dimiliki oleh populasi tersebut[10].Populasi yang digunakan dalam penelitian ini adalah sistem aplikasi e-Faktur dan e-Nofa pada kantor PT. Rajawali Property Jaya, sedangkan sampel yang digunakan adalah sistem aplikasi e-Faktur versi 2.1 dan e-Nofa berbasis website pada kantor.

Metode pengumpulan data yang digunakan dalam penelitian ini antara lain, dokumentasi, wawancara, dan observasi. Metode dokumentasi digunakan untuk memperoleh data tentang prosedur e-Faktur dan e-Nofa.Penelitian ini juga menggunakan tehnik wawancara dalam mengumpulkan data di mana peneliti mengadakan tanya jawab secara langsung kepada pihak berwenang yang merupakan staf dan Direktur.Metode pengumpulan data dengan observasi digunakan untuk mengamati proses kerja dari sistem-Faktur dan e-Nofa. 
Metode analisis data digunakan untuk mengetahui bagaimana penerapan e-Faktur dan e-Nofa sebagai perbaikan sistem administrasi pajak pertambahan nilai persepsi PT. Rajawali Property Jaya. Statistik deskriptif adalah statistik yang digunakan untuk menganalisa data dengan cara mendeskripsikan atau menggambarkan data yang telah terkumpul sebagaimana adanya tanpa bermaksud membuat kesimpulan yang berlaku untuk umum atau generalisasi. [10]

\section{HASIL DANPEMBAHASAN}

Elektronik Nomor Faktur (e-Nofa) adalah nomor seri yang didapatkan dari Direktorat Jendral Pajak bagi wajib pajak untuk menerbitkan faktur pajak elektronik, jika sebelumnya pelaporan kegiatan pajak yang berhubungan dengan penerbitan faktur pajak dilakukan secara manual dengan mendatangi kantor pelayana pajak maka dengan diberlakukannya e-Nofa, penerbitan nomor seri faktur pajak sudah berbasi online melalui aplikasi e-Faktur [11].

Penerapan e-Faktur dimulai melalui 3 tahap, tahap yang pertama pada 1 Juli 2014 diberlakukan untuk tahap awal/pencobaan yang berdomisili atau yang terdaftar di wilayah DKI Jakarta, tahap yang kedua pada 1 Juli 2015 diberlakukan khusus daerah pulau Jawa dan Bali, dan tahap yang ketiga pada 1 Juli 2016 untuk seluruh wilayah Republik Indonesia. PT. Rajawali Property Jaya sendiri melaksanakan penerapan $e$ Faktur pada tahun 2017.

Aplikasi yang digunakan pada PT. Rajawali Property Jaya adalah aplikasi $e$ Faktur windows 32 bit dengan versi terbaru yaitu versi 2.1.0.0. Adapun keuntungan yang dirasakan setelah menggunakan $e$-Faktur, yaitu:

a. Tanda tangan basah digantikan dengan tanda tangan elektronik, dengan adanya sertifikat elektronik dapat memudahkan Wajib Pajak dalam menandatangani faktur pajak sehingga Wajib Pajak tidak perlu lagi untuk menandatangani faktur pajak satu persatu

b. E-Faktur pajak tidak harus dicetak sehingga dapat mengurangi biaya kertas, biaya cetak, dan biaya penyimpanan dokumen, sehingga Wajib Pajak dapat mengurangi biaya dalam pencetakan faktur pajak

c. Nomor seri faktur pajak langsung dapat diakses melalui $e$-Nofa online sehingga Wajib Pajak tidak perlu lagi ke Kantor Pelayanan Pajak Pratama untuk meminta nomor seri faktur pajak. 
Dari hasil wawancara yang dilakukan dengan salah satu staf karyawan dan juga Direktur Perusahaan, peneliti menemukan penerapan e-nofa memiliki keunggulan serta kelemahan. Keunggulannya antara lain yaitu lebih tertib adminitrasi dibandingkan dengan sebelum penerapan serta dapat meminimalisir terjadinya kecurangan seperti penerbitan faktur pajak fiktif dan faktur pajak nomor berganda. Sedangkan kelemahan dari penerapan e-nofa adalah yaitu koneksi internet dan ketergantungan dengan jaringan internet sedangkan penyebaran internet masih belum merata secara nasional, sehingga dalam membuat faktur pajak harus memiliki koneksi internet terlebih dahulu, sehingga ruang gerak perusahaan agak terbatas untuk membuat dan mencetak faktur pajak. Namun sistem sangat diapresiasi oleh direksi perusahaan dikarenakan tidak perlunya tanda tangan basah ataupun stempel dari perusahaan, sehingga seorang karyawan bisa membuat faktur pajak tanpa harus menunggu kedatangan seorang direktur untuk ditanda tangani.

\section{KESIMPULAN}

E-Faktur adalah faktur pajak yang dibuat melalui aplikasi atau sistem elektronik yang ditentukan dan/atau disediakan oleh Direktorat Jendral Pajak [11]. Dengan adanya aplikasi faktur pajak elektronik ini merupakan sebuah sarana yang dapat mempermudah perusahaan dalam pembuatan faktur pajak. PT Rajawali Property Jaya menerapkan aplikasi $e$-Faktur pajak pada Tahun 2017, berdasarkan hasil penelitian dan pembahasan diatas maka penulis menyimpulkan bahwa, penerapan $e$-Faktur dalam pembuatan faktur pajak pada perusahaan klien sudah berjalan dengan baik. Adapun beberapa kendala yang sering dihadapi oleh perusahaan dalam menggunakan aplikasi $e$-Faktur masih bisa diatasi hanya saja perlu perhatian yang lebih, khususnya dalam jaringan internet yang terkadang lambat atau tidak mendukung sehingga dalam mengupload faktur pajak sering gagal.Dalam hal penerapan $e$-Faktur untuk pelaporan SPT masa PPN, pembuatannya dilakukan dalam satu aplikasi $e$-Faktur. Namun, untuk pelaporannya perusahaan menggunakan $e$-Feeling, meskipun demikian tetap masih ditemukan adanya keterlambatan dalam pelaporannya.

\section{SARAN}

Berdasarkan hasil penelitian dan pembahasan yang dijabarkan diatas, berikut ini adalah beberapa saran yang dapat disampaikan oleh penulis. Diharapkan saran ini dapat 
memberikan masukan dan bahan pertimbangan bagi pihak-pihak yang tertarik dengan judul penelitian ini. Beberapa saran tersebut antara lain, sosialisasi secara meluas mengenai penerapan $e$-Faktur dan $e$-Nofa kepada Wajib Pajak khususnya Pengusaha Kena Pajak perlu lebih ditingkatkan, agar manfaat dan tujuan penerapan $e$-Faktur dan $e$ Nofamampu menimbulkan kesadaran bagi Pengusaha Kena Pajak untuk memanfaatkan fasilitas online yang disediakan oleh Direktorat Jenderal Pajak. Perlu dilakukan penyempurnaan secara terus menerus terhadap sistem $e$-Faktur dan $e$-Nofa sehingga dapat meminimalkan hambatan dan error yang sering terjadi dalam penerapannya.

\section{DAFTAR PUSTAKA}

[1] Republik Indonesia. Peraturan Direktorat Jenderal Pajak Nomor PER11/PJ/2013perubahan atas peraturan nomor PER-44/PJ/2010 tentang Bentuk, Isi, dan Tata Cara Pengisian serta Penyampaian Surat Pemberitahuan Masa Pajak Pertambahan Nilai (SPT Masa PPN).

[2] Agoes, Sukrisno, dan EstralitaTrisnawati. 2017. Akuntansi Perpajakan. Edisi 3. Jakarta:SalembaEmpat,.

[3] Halim, Abdul. 2014. Perpajakan (Konsep, Aplikasi, Contoh dan Studi Kasus). Jakarta: SalembaEmpat.

[4] Ferdiawan, Erick. 2015. Implementasi Elektronik Nomor Seri Faktur Pajak Sebagai Upaya Perbaikan Sistem Administrasi Pajak PertambahanNilai. Jurnal Perpajakan (JEJAK) Volume 6, Nomor 2.

[5] Mardiasmo. 2018. Perpajakan. Edisi Terbaru. Yogyakarta: Andi Offset.

[6] Hardi, Andi dan Sjafardamsah. 2016. Solusi Sukses e-Faktur. Edisi Pertama. Jakarta: Mitra Wacana Media.

[7] Republik Indonesia. PeraturanDirektoratJenderalPajakNomorPER- 16/PJ/2014 tentang Tata Cara Pembuatan Dan Pelaporan Faktur Pajak Berbentuk Elektronik.

[8] Republik Indonesia. Undang-Undang Republik Indonesia Nomor 42 Tahun 2009 tentang Perubahan Ketiga Atas Undang-Undang Nomor 8 Tahun 1983 tentang Pajak Pertambahan Nilai Barang Dan Jasa Dan Pajak Penjualan Atas Barang Mewah.

[9] Setyawati, VitrianiAyu. 2016. Analisis Penerapan Elektronik Nomor Faktur (E-Nofa) Sebagai Upaya Mencegah Penerbitan Faktur Pajak Fiktif.Jurnal Perpajakan (JEJAK) Volume 8Nomor 1.

[10] Sugiyono. 2013. Metode Penelitian Bisnis. Bandung:Alfabeta.

[11]Republik Indonesia. Peraturan Direktorat Jenderal Pajak Nomor PER- 16/PJ/2014 tentang Tata Cara Pembuatan Dan Pelaporan Faktur Pajak Berbentuk Elektronik. 